\title{
Survey and Records of Mealy Bugs Species on Cotton and Alternate Host of Key Mealy Bug Phenacoccus solenopsis Tinsley and its Natural Enemies Complex in Major Cotton Growing Areas of South Tamil Nadu, India
}

\author{
K. Bharathi* and N. Muthukrishnan \\ Department of Agricultural Entomology, Agricultural College and Research Institute, \\ Tamil Nadu Agricultural University, Madurai, Tamil Nadu, India \\ *Corresponding author
}

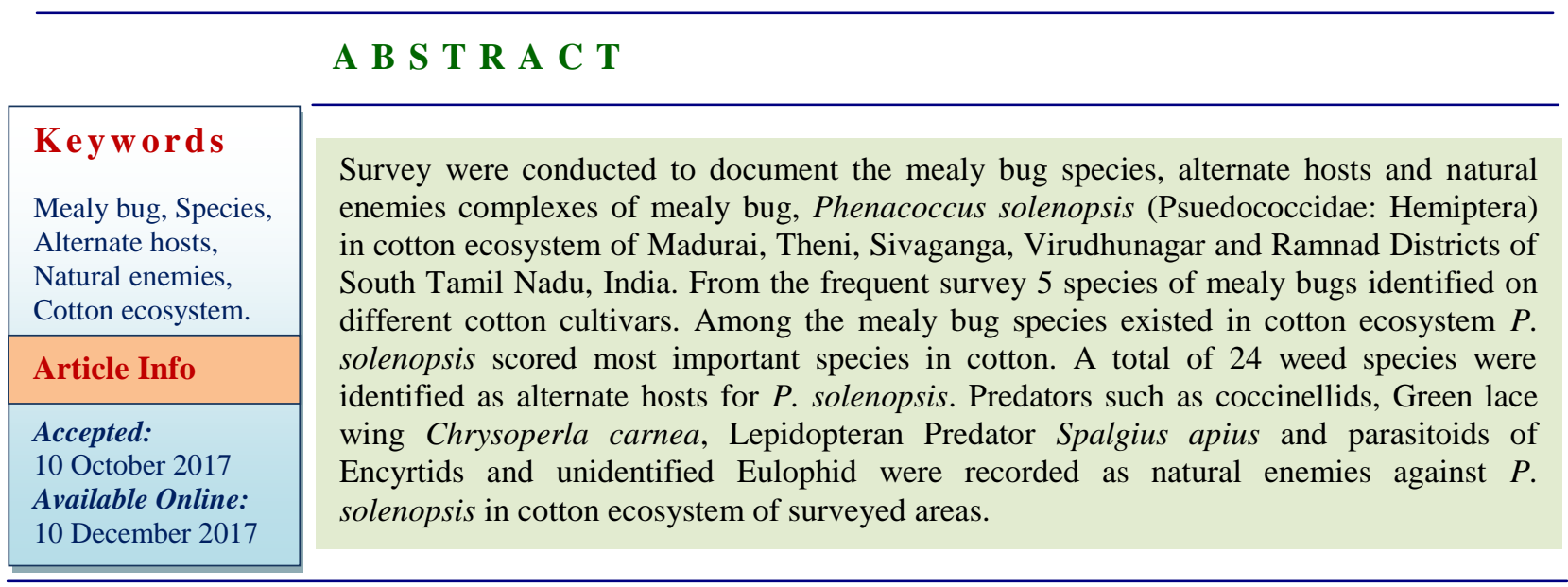

\section{Introduction}

About 5000 species of mealy bugs have been recorded from 246 families of plants throughout the world. Among these, 56 species have been reported from 15 genera of the family Malvaceae, including cotton and many other plants of economic importance (Ben-Dov, 1994). Mealy bug, Phenacoccus solenopsis Tinsley was described originally from the USA (Tinsley, 1898) and prevalent till 1992 (Ben-Dov, 2004). P. solenopsis has been recorded from 154 plant species including field crops, vegetables, ornamentals, weeds, bushes and trees. Most of these plants belong to the families Malvaceae, Solanaceae, Asteraceae, Euphorbiaceae,
Amaranthaceae and Cucurbitaceae. Fuchs et al., (1991) provided the first report of $P$. solenopsis infesting cultivated cotton in USA. Moreover, mealy bugs were never considered as major pests on cotton in India (APCoAB, 2006). Mealy bugs, P. solenopsis caused severe economic damage to Gossypium $\mathrm{sp}$ and reduced the yield up to 40-50 per cent in several parts of Gujarat (Dhawan, 2008). The unforeseen occurrence of mealy bug $P$. solenopsis in cotton and weed hosts create a new problem in cotton cultivation and pest management. There are very limited information on this pest and associated biotic factors. However, the present investigation 
was under taken during 2007 -2009 in major cotton growing areas of South Tamil Nadu, India.

\section{Materials and Methods}

Intensive surveys were conducted to collect and record the different species of mealy bugs and Alternate hosts and Natural enemies of Mealy bug, P. solenopsis on cotton plants during the year 2007 - 2009 that existed in the cotton ecosystem in Madurai, Theni, Sivaganga, Virudhunagar and Ramnad Districts of Tamil Nadu, India. Population of crawlers and adults of mealy bugs per $5 \mathrm{~cm}$ apical shoot was recorded from 10 randomly selected cotton plants in a field and three fields in a place. Per cent infested cotton plants due to mealy bugs (either on leaves, shoots and bolls separately or together) were estimated from 100 randomly selected plants in a field and three fields in a place.

Intensity grading was also estimated based on National Centre for Integrated Pest Management (NCIPM) grade of description of symptom ( 0 for no mealy bug, 1 for scattered appearance of few mealy bugs in the plant, 2 for severe incidence of mealy bug on any one branch of the plant, 3 for severe incidence of mealy bug on more than one branch or half portion of the plant, and 4 for severe incidence of mealy bug on the whole plant) from 10 randomly selected plants (Anon., 2007).

\section{Collection and Identification of mealy bugs species}

Field collected mealy bugs from cotton plants were brought to the laboratory, preserved in 70 per cent ethyl alcohol and mounted on slides (Borror et al., 1992). The specimens were identified by taxonomic keys (Williams and Watson, 1988) and with the repository collection of coccids kept in Department of
Agricultural Entomology, Tamil Nadu Agricultural University, Coimbatore.

\section{Collection and identification of alternate hosts}

Mealy bug infested weed plants in cotton ecosystem were also collected and their identification was accomplished with the help of weed scientists of the Department of Agronomy, Agricultural College and Research Institute, Madurai.

\section{Collection and identification of natural enemies}

\section{Predators}

Coccinellid predators collected from mealy bug infested cotton plants were killed using ethyl acetate and preserved. They were identified by using standard taxonomic keys of common species of Coccinellidae (Poorani, 2004) and with the repository collection of Department of Agricultural Entomology, AC\&RI, Madurai.

\section{Parasites}

The field collected mealy bug species from cotton plants were brought to the laboratory and kept in emergence cages. The parasitoids emerged from the mealy bug colonies samples were properly preserved and sent to the Insect Systematic Laboratory, Department of Entomology, Faculty of Agriculture, Annamalai University, Chidambaram, Tamil Nadu.

\section{Results and Discussion}

Mealy bug management is one of the greatest challenges to the farmers due to diversity of species. Careful identification and documentation of the mealy bug species are essential before control practices can be used. 
During the survey and surveillance, solenopsis mealy bug, Phenacoccus solenopsis Tinsley; two tailed mealy bug, Ferrisia virgata Ckll. and Pink Hibiscus mealy bug, Maconellicoccus hirsutus Green and Papaya mealy bug, Paracoccus mariginatus Williams and Granara de Willink were recorded on cotton cultivars at various locations of Madurai, Theni, Sivaganga, Viruthunagar and Ramnad districts of Tamil Nadu (Table 1). Among the mealy bug species identified $P$. solenopsis was the major species on cotton from the areas surveyed.

In Madurai District, Agricultural College and Research Institute (AC\&RI), Madurai, Pannikundu, Thirumangalam and Karumathur locations were surveyed for the incidence of mealy bug species. Table 1 elucidated that $P$. solenopsis was observed in AC\&RI Madurai, Pannikundu, Thirumangalam and Karumathur locations on MCU 7, Bt bunny and SVPR 2 cultivars with a population range of 27.2 (on MCU 7 in Thirumangalam) to 38.9 (on $B t$ bunny in AC\&RI, Madurai) per $5 \mathrm{~cm}$ apical shoot. P. solenopsis was also noted on MCU 7 with a population of 36.9 per $5 \mathrm{~cm}$ apical shoot in AC\&RI, Madurai, and SVPR 2 in Pannikundu (31.8 per $5 \mathrm{~cm}$ apical shoot) and Karumathur (36.3 per $5 \mathrm{~cm}$ apical shoot). $F$. virgata was recorded on $B t$ bunny in AC\&RI, Madurai (35.4 per $5 \mathrm{~cm}$ apical shoot) and on SVPR 2 in Karumathur (29.3 per $5 \mathrm{~cm}$ apical shoot). M. hirsutus was seen only on SVPR 2 (37.3 per $5 \mathrm{~cm}$ apical shoot) in Pannikundu areas.

Infestation due to $P$. solenopsis varied from 67.5 to 77.5 per cent on all the three varieties in all the four locations in Madurai District. Maximum infestation was observed on MCU 7 in Thirumangalam followed by SVPR 2 $(73.5 \%)$ in Karumathur, and Bt bunny (72.3\%) and MCU 7 (69.5\%) in AC\&RI, Madurai. However, P. solenopsis registered minimum infestation on SVPR 2 in
Pannikundu. Infestation due to $F$. virgata was maximum on SVPR 2 (76.3\%) in Karumathur and on Bt bunny $(72.3 \%)$ in AC\&RI, Madurai. But, M. hirsutus registered only 54.6 per cent infestation on SVPR 2 in Pannikundu.

Intensity grade of $P$. solenopsis arrayed from 2.8 to 3.7 on cotton cultivars in Madurai District. This was maximum on $B t$ bunny in AC\&RI and on SVPR 2 in Karumathur. The grade was 3.6 and 3.3 on MCU 7 in Thirumangalam and AC\&RI respectively. However, the grade was minimum on SVPR 2 in Pannikundu. $F$. virgata registered maximum grade of 3.6 on $B t$ bunny in AC\&RI, and 3.4 on SVPR 2 in Karumathur. SVPR 2 in Pannikundu however registered lowest intensity grade of 2.0. In Theni District, the surveyed locations were Agricultural Research Station Vaigai Dam and Jayamangalam. P. solenopsis alone was recorded in both surveyed areas. The population of $P$. solenopsis varied from 35.6 to 27.9 per $5 \mathrm{~cm}$ shoot. The population was maximum on MCU 7 and minimum on Supriya in ARS Vaigai Dam. However, the population was 33.3 per $5 \mathrm{~cm}$ shoot on Supriya in Jayamangalam village. A range of 23.5 to 52.0 per cent $P$. solenopsis infestation was observed. Maximum infestation was recorded on Supriya in Jayamangalam followed by on MCU 7 (45.7\%) in ARS Vaigai Dam. However, Supriya in ARS Vaigai Dam registered minimum infestation. The intensity grade was 2.3 on MCU 7 (ARS Vaigai Dam) and Supriya (Jayamangalam). It was 1.8 on Supriya in ARS Vaigai Dam.

In Sivaganga District, survey was conducted only in Illayankudi, where in P. solenopsis alone and not any other mealy bug species was observed. In Illayankudi, population was higher (40.2/ $5 \mathrm{~cm}$ shoot), infestation was maximum $(76.5 \%)$ and the intensity grade was also more (3.6). 
Table.1 Survey and surveillance of mealy bug species on cotton

\begin{tabular}{|c|c|c|c|c|c|}
\hline Locations & $\begin{array}{l}\text { Variety/ } \\
\text { Hybrid }\end{array}$ & $\begin{array}{l}\text { Observed mealy } \\
\text { bug spp. }\end{array}$ & $\begin{array}{c}\text { No of mealy } \\
\text { bugs per } 5 \mathrm{~cm} \\
\text { apical shoot } *\end{array}$ & $\begin{array}{c}\text { Infested } \\
\text { plants } \\
(\%) * *\end{array}$ & $\begin{array}{c}\text { Intensity } \\
\text { grade } \\
* * *\end{array}$ \\
\hline \multicolumn{6}{|l|}{ 1. Madurai } \\
\hline \multirow{3}{*}{ AC\&RI } & MCU 7 & $\begin{array}{l}\text { Phenacoccus } \\
\text { solenopsis Tinsley }\end{array}$ & 36.9 & 69.5 & 3.3 \\
\hline & \multirow{2}{*}{$\begin{array}{l}B t \\
\text { Bunny }\end{array}$} & P. solenopsis & 38.9 & 72.3 & 3.7 \\
\hline & & Ferrisia virgata Ckll. & 35.4 & 72.3 & 3.6 \\
\hline Thirumangalam & MCU 7 & P. solenopsis & 27.2 & 77.5 & 3.6 \\
\hline \multirow[b]{2}{*}{ Pannikundu } & \multirow[b]{2}{*}{ SVPR 2} & P. solenopsis & 31.8 & 67.5 & 2.8 \\
\hline & & $\begin{array}{l}\text { Maconellicoccus } \\
\text { hirsutus Green }\end{array}$ & 37.3 & 54.6 & 2.0 \\
\hline \multirow{2}{*}{ Karumathur } & \multirow{2}{*}{ SVPR 2} & P. solenopsis & 36.3 & 73.5 & 3.7 \\
\hline & & F. virgata & 29.3 & 76.3 & 3.4 \\
\hline \multicolumn{6}{|l|}{ 2. Theni } \\
\hline \multirow{2}{*}{ ARS (Vaigai Dam) } & Supriya & P. solenopsis & 27.9 & 23.5 & 1.8 \\
\hline & MCU 7 & P. solenopsis & 35.6 & 45.7 & 2.3 \\
\hline Jayamangalam & Supriya & P. solenopsis & 33.3 & 52.0 & 2.3 \\
\hline \multicolumn{6}{|l|}{ 3. Sivaganga } \\
\hline Illayankudi & SVPR 2 & $\begin{array}{l}\text { Paracoccus } \\
\text { mariginatus Williams }\end{array}$ & 40.2 & 76.5 & 3.6 \\
\hline \multicolumn{6}{|l|}{ 4. Virudhunagar } \\
\hline Aruppukottai & $\begin{array}{l}\text { LRA } \\
5166 \\
\end{array}$ & P. solenopsis & 30.8 & 40.5 & 2.1 \\
\hline Thadampatti & MCU 7 & P. solenopsis & 28.6 & 57.5 & 2.6 \\
\hline Kattangudi & MCU 7 & P. solenopsis & 32.8 & 45.0 & 2.2 \\
\hline Yerampatti & SVPR 2 & P. solenopsis & 33.4 & 68.5 & 2.5 \\
\hline P. N. Pudhupatti & SVPR 2 & P. solenopsis & 28.4 & 42.5 & 2.0 \\
\hline Kallikudi & SVPR 2 & P. solenopsis & 30.9 & 61.5 & 3.0 \\
\hline ARS Srivilliputhur & SVPR 2 & P. solenopsis & 28.9 & 70.5 & 3.3 \\
\hline \multicolumn{6}{|l|}{ 5. Ramnad } \\
\hline Saligramum & MCU 7 & P. solenopsis & 43.1 & 82.0 & 3.8 \\
\hline
\end{tabular}


Table.2 Alternate host of mealy bug $P$. solenopsis in cotton ecosystem

\begin{tabular}{|c|c|c|c|}
\hline S. No. & Scientific Name of the Weeds & English/Vernacular Name & Family \\
\hline 1. & Abutilon indicum L. & Kakai, Thutthi & Malvaceae \\
\hline 2. & Parthenium hysterophorus L. & $\begin{array}{l}\text { Whitetop Weed, Congress grass, } \\
\text { Feverfew }\end{array}$ & Asteraceae \\
\hline 3. & Trianthema protulacastrum.L. & horse purslane & Aizoaceae \\
\hline 4. & Pavonia zeylanica (L.) Cav. & Senegal & Malvaceae \\
\hline 5 . & Acalypha indica $\mathrm{L}$. & Kuppi, Kuppaimeni & Euphorbiaceae \\
\hline 6. & Cleome viscosa $\mathrm{L}$. & Asian spider flower & Capparaceae \\
\hline 7. & Tridax procumbens $\mathrm{L}$. & Coat Buttons & Asteraceae \\
\hline 8. & Euphorbia hirta, & Asthma Weed & Euphorbiaceae \\
\hline 9. & Achyranthes aspera $\mathrm{L}$. & Latjeera, Prikly Chaff flower & Amaranthaceae \\
\hline 10. & Boerhaavia diffusa $\mathrm{L}$. & Tar vine, Punarnava & Nyctaginaceae \\
\hline 11. & Corchorus trilocularis L. & Wild Jute & Tiliaceae \\
\hline 12. & Commelina benghalensis $\mathrm{L}$. & $\begin{array}{l}\text { Benghal dayflower, Tropical } \\
\text { Spiderwort }\end{array}$ & Commelinaceae \\
\hline 13. & Phyllanthus amarus Webster & Niruri, Kizha Nelli & Phyllanthaceae \\
\hline 14. & Phyllanthus maderaspatensis $\mathrm{L}$. & Stonebreaker, Keela Nelli & Phyllanthaceae \\
\hline 15. & Vernonia cinerea (L.) Less. & $\begin{array}{l}\text { Little Ironweed, Ash-Coloured } \\
\text { Fleabane, Goat-Weed }\end{array}$ & Asteraceae \\
\hline 16. & Portulaca oleracea $\mathrm{L}$. & Purslane little, hogweed & Portulacaceae \\
\hline 17. & Sida spinosa $\mathrm{L}$. & Prickly Fanpetals & Malvaceae \\
\hline 18. & Digera arvensis Forsk & Diagra, Tandla & Amaranthaceae \\
\hline 19. & Eclipta prostrata $\mathrm{L}$. & False Daisy, karisalankanni & Asteraceae \\
\hline 20. & Euphorbia geniculata $\mathrm{L}$. & Mexican fireplant & Euphorbiaceae \\
\hline 21. & Corchorus capsularis $\mathrm{L}$. & Tossa jute & Tiliaceae \\
\hline 22. & Cyanotis axillaris Roem and Sch. & Spreading dayflower, Neer-pulli & Commelinaceae \\
\hline 23. & Cyanotis cuculata Kunth & & Commelinaceae \\
\hline 24. & Ageratum conyzoides $\mathrm{L}$. & Ageratum & Asteraceae \\
\hline 25. & Cynodon dactylon Pres. & Bermuda Grass, Ghass & Gramineae \\
\hline 26. & Cyperus rotundus Linn. & Sedge grass, Nut rass, Korai, & Cyperaceae \\
\hline
\end{tabular}


In Virudhunagar District, survey was conducted in six places like Aruppukottai, Thadampatti, Kattangudi, Yerampatti, P. N. Pudhupatti, Kallikudi and ARS Srivilliputhur. In all the surveyed cotton cultivars (LRA 5166, MCU 7 and SVPR 2) of Virudhunagar District, only $P$. solenopsis was recorded and not any other mealy bug species.

The population varied from 28.4 to 33.4 per 5 cm shoot. Maximum population was observed on SVPR 2 in Yerampatti followed by on MCU 7 (32.8/5 cm shoot) in Kattangudi, on SVPR $2(30.9 / 5 \mathrm{~cm}$ shoot) in Kallikudi and on LRA 5166 (30.8/5 cm shoot) in Aruppukottai. Minimum population of 28.9 per $5 \mathrm{~cm}$ shoot was seen on SVPR 2 in ARS Srivilliputhur followed on MCU $7(28.6 / 5 \mathrm{~cm}$ shoot $)$ in Thadampatti and on SVPR $2(28.4 / 5 \mathrm{~cm}$ shoot) in P.N. Pudhupatti.

Infestation of $P$. solenopsis in Virudhunagar District arrayed from 40.5 to 70.5 per cent. Maximum infestation was noticed on SVPR 2 in ARS Srivilliputhur followed by on the same cultivar in Yerampatti $(68.5 \%)$ and Kallikudi (61.5\%); and on MCU 7 (57.5\%) in Thadampatti. Minimum infestation however was observed on LRA 5166 in Aruppukottai. This was followed by on SVPR $2(42.5 \%)$ in P.N. Pudhupatti and on MCU $7(45.0 \%)$ in Kattangudi (Table 1).

A range of 2.0 to 3.2 intensity grade was recorded due to $P$. solenopsis. Cultivar SVPR 2 registered intensity grade of 2.0, 2.5, 3.0 and 3.3 in P.N. Pudhupatti, Yerampatti, Kallikudi and ARS Srivilliputhur respectively. Lesser intensity grade of 2.2 and 2.6 was noticed on MCU 7 in Kattangudi and Thadampatti. Minimum grade of 2.1 was recorded on LRA 5166 in Aruppukottai.

In Ramnad District, MCU 7 cotton fields of Saligramum were surveyed for the mealy bug species. Only $P$. solenopsis was noticed.
Population of 43.1 per $5 \mathrm{~cm}$ shoot, infestation of 82.0 per cent and intensity grade of 3.8 were observed (Table 1b.)

Present records are in accordance with earlier findings of Kaur et al., (2008) who reported that in general, $P$. solenopsis is a common mealy bug species on cotton throughout India. The results of present survey confirmatory of the results of Suresh (2008) who also reported the occurrence of $P$. solenopsis, $M$. hirsutus, $F$. virgata and Malvastrum mealy bug, Ferrisia malvastra (Mc Daniel) in India and Tamil Nadu on various plants. Sporadic occurrence of $M$. hirsutus on cotton in Central Gujarat was also reported by Jhala and Bharpoda (2008).

\section{Alternate hosts of mealy bug, $\boldsymbol{P}$. solenopsis in cotton ecosystem}

Mealy bug, Phenacoccus solenopsis was recorded on 26 weed plant species such as Abutilon indicum L., Parthenium hysterophorus L., Trianthema protulacastrum. L., Pavonia zeylanica (L.) Cav., Acalypha indica L. Cleome viscosa L., Tridax procumbens L., Euphorbia hirta, Achyranthes aspera L., Boerhaavia diffusa L., Corchorus trilocularis L., Commelina benghalensis L., Phyllanthus amarus Webster, Phyllanthus maderaspatensis L, Vernonia cinerea (L.) Less, Portulaca oleracea L, Sida spinosa L., Digeria arvensis Forsk, Eclipta prostrata L., Euphorbia geniculata L, Corchorus capsularis L., Cyanotis axillaris Roem \& Sch., Cyanotis cuculata Kunth, Ageratum conyzoides L., Cynodon dactylon Pres. and Cyperus rotundus Linn., in cotton ecosystem. However, major occurrence of $P$. solenopsis was seen on Trianthema protulacastrum, $T$. monogena and Parthenium hysterophorus in all the surveyed locations. Nagrare et al., (2009) also observed the multiplication of $P$. solenopsis on the weed, P. hysterophorus 
growing on field bunds, water channels and wastelands and their movement on to the cotton plants during the cropping season. Arif et al., (2009) recorded $P$. solenopsis from 154 plant species including field crops, vegetables, ornamentals, weeds, bushes and trees. Probably proper weed management and field sanitation practices may reduce the mealy bug occurrence and further flareup (Table 2).

\section{Natural Enemies of cotton mealy bug $\boldsymbol{P}$. solenopsis}

\section{Predators}

From the survey following predators also recorded on $P$. solenopsis infested cotton ecosystem such as Coccinellids: Scymnus coccivora Ayyar, Cryptolaemus montrouzieri (Mulsant), Cheilomenes sexmaculata (Fabricius), Brumoides suturalis (Fabricius), Coccinella transversalis F., Coccinella septempunctata Linnaeus, Harmonia spp; Chrysopids: Chrysoperla carnea (Stephens) and Lepidopteran: Spalgius epius (Westwood). Population of coccinellids was maximum followed when compared to the chrysopids.

\section{Parasitoids}

During the survey period six different hymenopteran parasitoids viz., Aenasius bambawalei Hayat, Promuscidea unfasciativentris Girault, Anagyrus kamali Moursi, Prochiloneurus spp., Leptomastix nigrocoxalis Compere and one Eulophid were identified from the cotton mealy bug $P$. Solenopsis. The occurrence of these parasitoids had earlier been reported on various mealy bugs species (Sinha et al., 1985 and Hayat, 1986). Recently these parasitoids had also been recorded from coccids on Hibiscus rosasinensis in Maharastra (Sureshan and Narendran, 2005).

\section{References}

APCoAB, 2006. Bt cotton in India: a status report. New Delhi, India, Asia pacific consortium on agricultural biotechnology, p 34.

Arif, M. I., Rafiq, M. and Ghaffar, A. 2009. Host Plants of Cotton Mealybug (Phenacoccus solenopsis): A New Menace to Cotton Agroecosystem of Punjab, Pakistan. Int. J. Agric. Biol., 11: 163-167.

Ben-Dov, Y. 1994. A systematic catalogue of the mealybugs of the world. Intercept Unlimited. pp 686.

Ben-Dov, Y. 2004. Scale Net, Phenacoccus solenopsis. Available from: http://198. 77.169.79/catalogs/pseudoco/Phenacocc ussolenopsis.htm (Accessed 9 September 2004).

Dhawan, A. K. 2008. Historical perspective of various species as cotton pests in India and rest of the world and factor affecting occurrence and outbreak on cotton. In: Proceedings of the National Consultation on Mealy bug Management, Central Institute for Cotton Research, Nagpur, India, 28-29 January 2008, pp. 11-14.

Fuchs, T. W., Stewart, J. W., Minzenmayer, R. and Rose, M. 1991. First record of Phenacoccus solenopsis Tinsely in the United States. Southwestern Entomol., 16: 215-221.

Hayat, M. 1986. Family Aphelinidae. (In: Subba Rao. B. R.; Hayat, M. (Eds.) The Chalcidoidea (Insecta: Haymenoptera) of India and the adjacent countries. Part II.) Oriental insects. 20:170.

Nagrare, V. S., Kranthi, S., Biradar, V. K., Zade, N. N., Sangode, V., Kakde, G., Shukla, R. M., Shivare, D., Khadi, B. M. and Kranthi, K. R. 2009. Widespread infestation of the exotic mealybug species, Phenacoccus 
solenopsis (Tinsley) (Hemiptera: Pseudococcidae) on cotton in India. Bull. Entomol. Res., 19: 1-5.

Poorani, J. 2004. Common species of coccinellidae of the Indian region. http://www.angelfire.com/bug2/j_poora ni/ladybirds.htm

Sinha, P. K., Sayeed, M. S. and Dinesh, D. S. 1985. A report on the mealy bugs (Hemiptera: Pseudococcidae), their host plants and natural enemies at Bhagalpur. In: Proceeding of the National Academy of science. India (B), 55 (2):13-17.

Sureshan, P. M. and Narendaran, T.C. 2005. Description of a new species of Ophelosia Riley with synonymic and taxonomic notes on Indian Eunotinae (Hymenoptera: Chalcidoidea: Pteromalidae). Zoo Print J., 20(5): 1984-1855.

Tanwar, R.K., Bhamare, V. K. Ramamurthy, V.V. Mohammad, H. Jeyakumar, P., Singh, A. and Bambawale, O. M. 2008. Record of new parasitoid on mealy bug Phenacoccus solenopsis. Indian J. Ento. 70(4):87-88.

Tinsley, J. D. 1898. Notes on coccidae, with descriptions of new species. Can. Entomol, 30: 317-320

Varshney. R. K. 1982. A review of Indian coccids (Homoptera: Coccidae). Oriental Insects, 19:1-101.

\section{How to cite this article:}

Bharathi, K. and Muthukrishnan, N. 2017. Survey and Records of Mealy Bugs Species on Cotton and Alternate Host of Key Mealy Bug Phenacoccus solenopsis Tinsley and its Natural Enemies Complex in Major Cotton Growing Areas of South Tamil Nadu, India. Int.J.Curr.Microbiol.App.Sci. 6(12): 1047-1054. doi: https://doi.org/10.20546/ijcmas.2017.612.118 